\title{
Abu Dhabi-Saudi Territorial Negotiations (1970-71): And the End of Britain's Dominance in the Gulf
}

\author{
Noura S. Al Mazrouei ${ }^{1}$ \\ ${ }^{1}$ Gulf Studies, Institute of Arab and Islamic Studies, University of Exeter, England \\ Correspondence: Noura S. Al Mazrouei, Gulf Studies, Institute of Arab and Islamic Studies, University of Exeter, \\ England. E-mail: Almazrouei2013@gmail.com
}

Received: June 17, 2014 Accepted: June 30, 2014 Online Published: September 26, 2014

doi:10.5539/ach.v7n1p141 URL: http://dx.doi.org/10.5539/ach.v7n1p141

\begin{abstract}
The subject matter of this paper is the examination of the UAE-Saudi territorial negotiations from 1970-1971. This study discusses Britain's mediation role in the Abu Dhabi-Saudi negotiations. Of particular note is Britain's role, which focused on managing the dispute instead of settling the Abu Dhabi-Saudi border disputes. This serves as an example of Britain's wish to avoid damaging its economic interests and political relations with either the UAE or Saudi Arabia. In line with this, the paper will examine King Faisal's proposal of 1970, Shaikh Zayid's position towards it and Saudi Arabia's and Abu Dhabi's negotiation strategies and tactics in settling the disputed areas. The paper offers a full explication of the major factors that hindered the dispute's resolution before Britain officially withdrew from the Gulf.
\end{abstract}

Keywords: Twin Pillar policy, neogitations, strategy, tactics, Abu Dhabi Petroleum Company ADPC, Exclusive Agreement

\section{Introduction}

Despite the fact that scholars have studied the British period extensively, there is a fairly large gap in existing literature related to UAE-Saudi Arabia territorial negotiations 1970-1971. There is a reason for this: only recently have enough government documents have been de-classified and released to the public to enable scholars to reassess the subject. In the absence of Saudi and Emirati governmental records, this study has had to rely heavily on British governmental records. Most British documents on the Abu Dhabi-Saudi border dispute used in this study were declassified only a few years ago and so period from 1970-71 is relatively unstudied field. Declassified British government documents have been available to the public only for a few years, since 2009. A selection of the most important documents was subsequently edited and Schofield in Arabian Boundaries, 1966-1975 (2009), Volumes 10 to 16. This important selection of documents has enabled me to examine the territorial negotiations of 1970-71 between the UAE and Saudi Arabia, an area that has been somewhat overlooked and should be addressed.

Britain's mediation in order to settle the border dispute between Abu Dhabi ${ }^{1}$ and Saudi Arabia during its last two years in the Gulf is examined, focusing on its "honest broker" ${ }^{2}$ role. It examines Britain's position towards the boundary question, which focused on its own interests in the disputed areas. This paper also examines how Abu Dhabi's position in the negotiations with Saudi Arabia weakened substantially when British played the honest broker role, while Saudi Arabia's position was strengthened considerably by the US government's Twin Pillar policy. This analysis will take place in reference to Shaikh Zayid's resistance to the British mediation role, and the Saudi proposal and is undertaken in order to answer one of the research questions: to ascertain what form Britain's role as mediator took and how it shaped the boundary question between Abu Dhabi and Saudi Arabia and their respective positions.

This paper has been divided into six major sections. Section one examines Britain's mediation in the boundary question between Abu Dhabi and Saudi Arabia and its implementation practices. In section two, King Faisal's proposal of 1970 will be examined, with reference to the disputed areas. This extends to an illustration of Shaikh Zayed's position towards King Faisal's proposal. Section three will examine how British interests, represented by the Abu Dhabi Petroleum Company's activities in the Zararah oilfield, played a vital role in directing Britain's policy towards the UAE-Saudi border disputes. Section four will analyse the factors involved in the context of the Abu Dhabi-Saudi border dispute, the question of the UAE federation and the Twin Pillar policy that complicated the boundary question and negotiations intended to take matters forward. Section five will analyse 
the Saudi-Abu Dhabi negotiation strategies and tactics that used in order to settle the border issue. The final section concludes, presenting the relevant analysis of all the examinations.

\section{Britain's Mediation Role}

On 4 May 1970 King Faisal offered to solve the issue of the disputed areas (Al-Ain/Buraimi ${ }^{3}$, Khor al-Udaid ${ }^{4}$, Liwa Oasis) region with Abu Dhabi by proposing a referendum on Al-Ain/Buraimi region in exchange for having sovereignty in South Liwa and Khor-al Udaid. ${ }^{5}$ In the negotiations concerning territorial dispute between the UAE and Saudi Arabia, this was a crucial date, since the King's offer would remain Saudi Arabia's firm negotiating position until the signing of the Saudi-UAE Treaty of Jeddah on 21 August 1974. The Foreign Office attempted to persuade Shaikh Zayid that, since Abu Dhabi was soon to become an independent state and because he was unlikely to get a more favourable deal than King Faisal proposal after British withdrawal from the Gulf, the disputed areas should be settled while Britain was still present in the region. To that end, Britain's appropriate course of action in the future would be consistent with its chosen role as an "honest broker" in dealing with Abu Dhabi-Saudi dispute. A Foreign Office official speculated that, in response to British oil company activity in the disputed Zararah/Shaybah region, Saudi Arabia would be "likely as a result of these drillings, [to] call off the current attempts, in which we are acting as 'honest broker' between the two sides, to negotiate a frontier settlement."

The "honest broker" role suggests that there were at least some British officials who saw Britain as a neutral mediator in dealing with Abu Dhabi-Saudi border dispute. However, this study reveals that the honest broker role was declared as a way of protecting the company's interests in the disputed areas: "we have an interest in seeing that profitability of this British company [ADPC] is not adversely affected by political difficulties over the boundary."

Following Saudi Arabia's settlement offer on 4 May 1970, British officials discussed Britain's role as mediator in the territorial dispute between Abu Dhabi and Saudi Arabia. For example, in June 1970 Sir Stewart Crawford, the Political Resident in Bahrain, argued:

We ought not to be involved in details of possible territorial concessions, but I doubt where we can stay out of this subject... it is true that the more involved we are the more we may be criticized for our role in the conclusion of any compromise settlement which [Zayid] may later regret, but I doubt whether this could be as damaging for British interests as a dispute between two Arab states. ${ }^{8}$

In the context of the British role as "honest broker", if Thomas Princen's typology of the mediation role ${ }^{9}$ is applied in the British case, it could be said that Britain acted as a "principal mediator" in the Abu Dhabi-Saudi border dispute because of its direct interests and involvement in the disputed areas — such as the Abu Dhabi Petroleum Company in Zararah oilfield. ${ }^{10}$

Some British officials could not agree about their support for the "honest broker" role. For example, Sir Francis Vallat, a former Foreign Office legal adviser, stated: "to some extent HMG was in an ambiguous position in that it was on the one hand responsible for the conduct of [Shaikh Zayid's] foreign affairs and on the other was seeking to act as a mediator between the Ruler [Shaikh Zayid] and King Faisal." "11 And in June 1970, the British Ambassador in Jeddah wrote an assessment of Britain's historical role in the Abu Dhabi-Saudi border dispute: "we are basing ourselves only on our own view of the legal justification for our action in 1955, which has never been accepted by the Saudis. ${ }^{12}$ The past history played a role that impacted on the development of current negotiations. ${ }^{13}$ As for the Saudis, they might not have trusted an honest broker at this stage, due to past history related to the Anglo-Saudi negotiations 1934-1955 that had led British unilaterally to enforce the Saudi frontier in 1955. Notwithstanding Saudi expectations of an honest broker, there were in practice two reasons why it would have been difficult for the British to apply an "honest broker" approach. First, a British oil company was drilling in the area affected by King Faisal's proposal of 1970, and secondly, the Exclusive Agreement of $1892^{14}$ remained in effect and the British still had an obligation to protect Abu Dhabi's interests.

An important question is what support Shaikh Zayid expected to receive from the British role in 1970 and 1971 ? According to a UAE diplomat, Shaikh Zayid had not expected that the issue of the disputed areas would remain unresolved by the time Britain withdrew from the Gulf in late 1971. ${ }^{15}$ As Crawford wrote to the FCO in May 1970, Shaikh Zayid was certain that "no solution could come to this problem simply from Abu Dhabi/Saudi negotiations and that HMG would in fact have to play a big role"16 in settling the dispute. 


\section{King Faisal's Proposal and Shaikh Zayid's Reaction}

When it occurred to Shaikh Zayid that Britain was not prepared to take an active part in finding a settlement for the disputed areas, he tried to arrange for regional mediators, and during the negotiation process from 1970 to 1971 attempted to enlist various states to intervene, especially after it was conceded that the British mediation was not effective. As his scheduled meeting with King Faisal on 6 May 1970 approached, Shaikh Zayid, without consulting the British, tried to recruit Kuwaiti officials as mediators to smooth things over with King Faisal. However, his first attempt was not successful. When Kuwaiti officials told King Faisal that Shaikh Zayid would use the meeting to discuss the disputed areas, King Faisal indicated that he was prepared to listen to Shaikh Zayid's views on his proposal. ${ }^{17}$ However, before Shaikh Zayid travelled to Jeddah, the British learnt about the Kuwaiti mediator through the British Ambassador in Kuwait, and Shaikh Zayid was told not to discuss the dispute but instead to use the meeting to talk about the proposed federation of nine emirates. ${ }^{18}$ As a result, when Shaikh Zayid met King Faisal on 6 May 1970 and acted as the British had advised him, the talks promptly broke down, because King Faisal said that he would not support any federation without first settling the disputed areas. ${ }^{19}$

Unfortunately, the conversation between King Faisal and Shaikh Zayid at the meeting on 6 May 1970 is redacted from the FCO document cited in the Arabian Boundaries documents. However, King Faisal's brother, Prince Fahd Al Saud, confirmed King Faisal proposals when he stated that: "the boundary problem can be compromised by a package that I would regard as saleable on our side; abandonment (with suitable face-saving) of territorial claims on the whole Buraimi oasis in return for concessions on the western and southern boundary [of Abu Dhabi] which could take account of established oil company interests. ${ }^{.20}$ Basically this represented King Faisal's proposal of 1970. At the meeting, King Faisal also demanded that drilling by ADPC should be suspended until a settlement for the disputed areas had been found.

In this context, when the outcome of the meeting did not meet King Faisal's expectations, Kamal Adham, Saudi consultant to King Faisal, declared that King Faisal, who was critical of Shaikh Zayid for not discussing the border dispute as the Kuwaitis had said he would, might resort to using force against Abu Dhabi. ${ }^{21}$ On 19 May the British Embassy in Kuwait reported that, according to the local Kuwaiti press: "Saudi Arabia is planning to take back the Buraimi oasis after British withdrawal in 1971.,22 The report seemed credible to the Foreign Office because, after King Faisal and Shaikh Zayid had met, Ambassador Morris reported King Faisal's comment that: "one way or another [the disputed areas] must be settled before the British left, and if not by negotiation then by other means." ${ }^{, 23}$

Furthermore, when ADPC continued its drilling operations after Shaikh Zayid's visit to Jeddah, King Faisal declared "if drilling was not stopped the Saudis might use force to remove the company's equipment. The ruler [Shaikh Zayid] was given until the end of June to reply to these demands. ${ }^{24}$ (See Figure 1). Shaikh Zayid was well aware of the much greater power of Saudi Arabia compared with Abu Dhabi, but was determined to resist Saudi territorial claims against Abu Dhabi. A British telegram of 31 May 1970 recorded Shaikh Zayid's view of King Faisal's proposal in the Indian newspaper Blitz; Shaikh Zayid said: "we are weak and they are strong but if they push us this will create resistance." 25

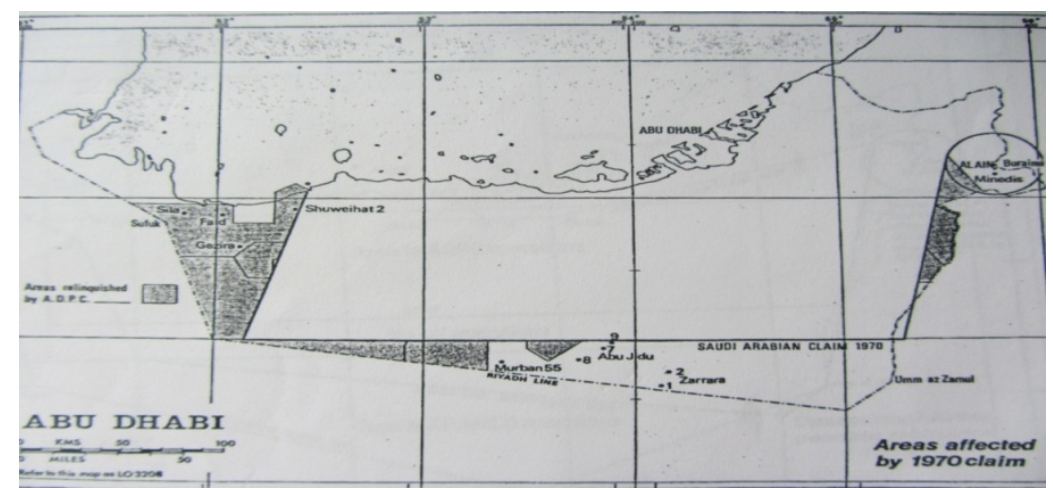

Figure 1. Location of Wells in Zararah Oilfield, South of Abu Dhabi

Source: Abu Dhabi Petroleum Company map showing location of oil field at Zararah in relation to Saudi claims of 1970. FCO/8 1338, in Arabian Boundaries, vol.11, 1970. p. 498. 
Bahrain was the second mediator, but its role was not successful either. Shaikh Isa bin Khalifa, the Ruler of Bahrain, expressed his anxiety about the instability that the Abu Dhabi-Saudi territorial dispute could bring to the Gulf. He told King Faisal that: "his attitude to Abu Dhabi could ruin the [Federation]"26

British government officials strongly opposed the involvement of both Kuwait and Bahrain ${ }^{27}$ in the negotiation process between Abu Dhabi and Saudi Arabia. ${ }^{28}$ In fact, although the British had failed to advocate on Shaikh Zayid's behalf under the Exclusive Agreement of 1892 against Saudi demands, they wanted to control the involvement of mediators, and interfered with Shaikh Zayid's attempts to arrange for mediators under the Exclusive Agreement. In addition, on 19 June 1970, the Foreign Office sent a telegram to the Political Residency in Bahrain:

We are glad that [the Political Agent in] Abu Dhabi has persuaded [Shaikh Zayid] not to approach the [US] state department at this stage. We must certainly consider carefully what role the Americans could play, but it should be for us on [Shaikh Zayid's] behalf and not [Shaikh Zayid] himself to bring them in as regards enlisting the services of intermediaries from the Gulf area [...] we doubt whether such intermediaries could play a particularly significant role at present. ${ }^{29}$

The British had informed the Americans that they should keep out of the boundary question since the British were having a hard time dealing with King Faisal. ${ }^{30}$ Here it is unclear why Shaikh Zayid would have considered asking the Americans to mediate in the Abu Dhabi-Saudi border dispute. The FCO documents cited in Arabian Boundaries are not helpful in this regard, so one can only speculate based on the available evidence. Certainly the United States had direct interests in aiding Aramco and protecting American military contracts with Saudi Arabia, and as partners with Saudi Arabia, the Americans could push the Saudis to make a reasonable concession.

\section{The Britain's Interests in the Disputed Areas}

In response to King Faisal's demands for ADPC drilling at Zararah to stop, the British took security measures in the Batin region, where the oil operations were located, to discourage any possible Saudi aggression south of Liwa. ${ }^{31}$ Shaikh Zayid also suggested relocating a squadron of the Abu Dhabi Defence Force from Al-Ain/Buraimi to the Umm al-Zamul area. ${ }^{32}$ In this context, the Saudi use of force might be not directed against all of Abu Dhabi's territories, but against ADPCs drilling operations in the south of Abu Dhabi only.

At the same time, British officials had drafted a suggested response for Shaikh Zayid to King Faisal's demand, which stated the following:

I believe that there must have been a misunderstanding between us about the outcome of our discussion in Riyadh. When we discussed drilling in the Batin [where is Zararah oilfield located], I had intended that my undertaking to your majesty should be confined to well one at Zararah only. In accordance with that undertaking, I gave instructions that drilling there should be halted...As your majesty will be aware, the oil company concerned is engaged in an extensive and important programme of exploration which it would be unreasonable to delay in view of the heavy expenditure which the company has already incurred. I have every hope that this programme will help in due course not only bring much needed development to the area but also to promote stability there. ${ }^{33}$

The draft reflects how British interests would be affected should ADPC have to suspend its activities and remove its equipment, which would cause considerable losses for the company. In fact, drilling was temporarily suspended on Zararah well no.1 but was shifted for drilling to continue on Zararah well no.3. [see Figure1.] When King Faisal learnt about the continuation of drilling, he demanded that it must stop in all the territory in question. ${ }^{34}$ Despite King Faisal's possible use of force to remove the company's equipment, ${ }^{35}$ an executive of the Abu Dhabi Petroleum Company wrote to the Foreign and Commonwealth Office requesting the British government to take steps to ensure the continuation of the ADPC's concession rights. ${ }^{36}$

British officials also promoted the settlement of the dispute as being both financially important for British oil companies and socially important for the people living in the areas. Correspondence between the Foreign Office and the Abu Dhabi Petroleum Company suggests that King Faisal's demands that ADPC's activities should be stopped meant that ADPC's interests were at stake, as the following telegram suggests: 
As the Saudi government will be aware, the Abu Dhabi Petroleum Company has for some time been engaged in a programme of exploration for oil resources, including drilling test wells, in what H.M Government and His Highness the ruler of [Abu Dhabi] regard as the southern part of Abu Dhabi territory. Some of these operations are in an area which his Majesty King Faisal has proposed should be regarded as Saudi territory in the proposals which he made to His Highness Shaikh [Zayid] on 4 May, 1970. Shortly after that date certain of the company's operation were temporarily suspended while his Majesty's proposals were being examined. However,... any delay in operations to explore and exploit such resources not only involves the company in considerable financial loss but, more important, postpones the day when the people of the area can benefit from these resources. ${ }^{37}$

This letter was written in July 1970, two months after King Faisal had demanded an end to ADPC drilling at the Zararah oilfield. It is interesting because it aligns British interests with the economic development of the area while attempting to limit ADPC's potential financial losses. However, King Faisal continued to pressure Shaikh Zayid and the British, beginning with a demand that drilling should stop at Zararah no.1. Shaikh Zayid had agreed to King Faisal's first demand at their previous meeting on 6 May 1970, but King Faisal later told the British that his demand had also included Zararah wells nos. 2, 3 and $4 .{ }^{38}$ Drilling operations had been continuing sporadically since May 1970 at a time when King Faisal's anger was escalating. The FCO reported that:

King [Faisal] accused Shaikh [Zayid] of allowing the Abu Dhabi Petroleum Company (ADPC) to drill in [Zararah] area just north of the modified Riyadh Line $^{39}$...which was regarded as Abu Dhabi territory but which, under the King's proposals, would become part of Saudi Arabia. He asked Shaikh Zayid to order ADPC to suspend drilling forthwith and threatened to remove their rig by force if this was not done. ${ }^{40}$

In light of this report, it is obvious that the major impediment to negotiations moving forward was that the Saudis and the British had different perspectives of the frontier lines on which their negotiations were based. The Saudis wanted drilling activities to be suspended in term of King Faisal's 1970 proposal. However, the limit of the Abu Dhabi Petroleum Company's concessions was drilling within the modified Riyadh line, which the Saudis had never recognised in the first phase of the Anglo-Saudi negotiations from 1935 to 1949.

In addition to protecting ADPC's interests as mentioned earlier, a proposal by William Luce included the creation of blocked accounts. Profits from oil production would be put into these blocked accounts and none of the money would be paid out "until Saudi Arabia and Abu Dhabi agreed to reach an agreement. Even if the sovereignty of Zararah is transformed [to Saudi Arabia] at any time in the future would not be impacted on [company's] right as a concessionaire." ${ }^{41}$ King Faisal and Shaikh Zayid both rejected Luce's proposal, and not long afterwards, C. J. Treadwell, the Political Resident, informed the Foreign Office that: "[Shaikh Zayid] thought that our advice to him on settling [south of Liwa] was coloured by our wish to protect our own political as well as British commercial interests. ${ }^{\prime 2}$ The Foreign Office acknowledged: "that [Luce's] proposal would not be in the interest of Abu Dhabi and Saudi Arabia even if they could be persuaded to accept it and that it might cast doubt in [Zayid's] mind on HMG's motives." ${ }^{43}$

It is important to note that Saudi Arabia's attempt to draw the British to its side by promising to protect the sovereignty rights of the ADPC's concessions over the disputed areas would be transferred to Saudi Arabia. Documented evidence in Arabian Boundaries strongly suggests that the British worked hard to protect the Abu Dhabi Petroleum Company and to satisfy the Saudis. According to a Foreign Office minute from October 1972, British officials secretly received assurances on at least three occasions that Saudi Arabia would honour the British oil company's concessions in the disputed areas. The correspondence between the British and the Saudis was dated May 1970, and Kamal Adham, King Faisal's advisor, also gave these assurances in June and in August. For example, on 22 August 1970, King Faisal told Sir William Luce: "the rights of existing oil concessionaries onshore and offshore would be preserved in any territory ceded by Abu Dhabi to Saudi Arabia", while Kamal Adham confirmed that British companies would keep the concession rights in their areas and would not be affected by any Abu Dhabi-Saudi Arabia border changes. ${ }^{44}$ In that context, the British were being prepared for a change in sovereignty over the disputed areas, namely in Zararah oilfield. Of course, these assurances encouraged the British to persuade Shaikh Zayid towards an agreement based on King Faisal's proposal. 


\section{The Abu Dhabi-Saudi Border Disputes in Context of the Federation Question and the Twin Pillar Policy}

The initial plan for a federation of nine Gulf States ${ }^{45}$ failed for a number of reasons, most notably the conflicting interests of the states themselves, along with Saudi Arabia's refusal to take a position on supporting a federation of nine states until the disputed areas with Abu Dhabi had been resolved. Later, seven states would unify as the United Arab Emirates. In term of the Abu Dhabi-Saudi border dispute the British were concerned about the future of a federation of the emirates, and in April 1971, the Political Agent in Abu Dhabi, C. J. Treadwell, wrote to the Political Resident in Bahrain:

There is a little hope for a union of nine. One unknown factor is the attitude of Saudi Arabia towards a federation of seven states including Abu Dhabi. Saudi Arabia's claim against Abu Dhabi territory might cause [Saudi Arabia] to hesitate before agreeing to recognise any federation of seven. ${ }^{46}$

Saudi Arabia's linking of dispute resolution to recognition of the UAE placed Shaikh Zayid in an extremely stressful position. In July 1971, the British Embassy in Jeddah suggested to the Foreign Office that "if it becomes clear that King Faisal will continue to oppose a Union until the boundary question is solved, it might be possible to persuade [Shaikh Zayid] that it would be worth making further territorial concessions. ${ }^{, 47}$ By linking its support for a federation to the resolution of the disputed areas, Saudi Arabia simply complicated the question of the boundary. Hussam Al-Ulama has commented that by linking the settlement of territorial dispute to diplomatic recognition of the future new federation, King Faisal wanted to weaken Abu Dhabi's negotiating position by making the matter into a heavy burden. ${ }^{48}$ In doing this, Saudi Arabia employed tactics of psychological warfare. According to Fisher and Ury, psychological warfare puts the threatened party under stress and thereby produces a subconscious desire to end the dispute by accepting the other party's demands. ${ }^{49}$

As far as the Foreign Office was concerned, the future United Arab Emirates was obliged to establish good relations with Saudi Arabia and Iran in order to ensure its own survival. In June 1970, the British Foreign Office declared:

We fully recognise Saudi Arabia's interest in the political stability of the Gulf. We recognise that Saudi Arabia and Iran will be the natural guardians of that stability after our military withdrawal... it is necessary that all three parties [the Emirate Rulers, the Saudis, and the Iranians] should agree among themselves. All this we say to the rulers, the Saudis and the Iranians, in the belief that this is also the best way of looking after our own considerable interests after $1971 .^{50}$

Saudi Arabia's position was strengthened in terms of the Twin Pillar policy, even though that policy remained problematic in terms of Abu Dhabi's future relations with both Iran and Saudi Arabia. In fact, Abu Dhabi had an outstanding territorial dispute with the Saudis, and at the same time, Sharjah and Ras al-Khaimah had territorial disputes with the Iranians over three islands in the Strait of Hormuz.

In addition to Saudi and British pressure to accept King Faisal's proposals, Shaikh Zayid also faced pressure from Iran. According to US government analysis of the Gulf region in August 1970, Iran's ambassador to Great Britain announced in London that Iran would not recognize or cooperate with a federation unless Iran was recognized as having sovereignty over the three islands claimed by Sharjah and Ras al-Khaimah. ${ }^{51}$

The Twin Pillar policy depended on Saudi Arabia and Iran to provide security for the Gulf. Like Great Britain with the Abu Dhabi-Saudi border dispute, the US was similarly positioned, and in significant ways was subordinated to its Twin Pillar policy. However, the Americans blamed the British for not pushing Shaikh Zayid hard enough towards a settlement and for not having played an effective mediation role in the early stages of negotiations. According to a State Department memorandum dated 27 September 1970:

The British have not been putting any serious pressure on [Shaikh Zayid] of Abu Dhabi to resolve his boundary dispute with the Saudis even though [King] Faisal for the last year has seemed unusually amenable to a settlement. The British do not believe this problem will prevent the formation of the proposed Trucial States Federation. We are not so confident; we doubt Faisal will recognize the federation so long as the boundary problem is unresolved. ${ }^{52}$

\section{Saudi Negotiation Strategy and Tactics}

From a close reading of the relevant documents in Arabian Boundaries, it is clear that in negotiating, the Saudis used a control strategy in which one party uses its power to dominate another negotiator. ${ }^{53}$ In theoretical terms, 'control strategy' is described from the winner's perspective as opposed to 'accommodation strategy', which is described from the perspective of the loser. ${ }^{54}$ This study shows that the Saudis successfully applied a control 
strategy using contentious tactics, and this strategy, which was employed by Saudi Arabia throughout the negotiation process, appears to have been characterized by "dirty tricks". The dirty tricks include "take it or leave it', refusal to negotiate, extreme demands, overt anger, harassment, fixed positional commitments, and threats (including threats of use of force).$^{55}$ Dirty tricks do not allow negotiations to proceed peacefully towards outcomes associated with mutual concessions.

The British archival records make it obvious that in implementing a control negotiation strategy the most aggressive tactics used by the Saudis were 'take it or leave it' and refusal to negotiate over King Faisal's proposal of May 1970. Jim Treadwell states: "any attempt to re-negotiate on the basis of Faisal's Take it or leave it would be quite useless." ${ }^{56}$ The Saudis made Shaikh Zayid's acceptance of King Faisal's terms a precondition for negotiations to proceed. For example, in August 1970, months before the plan for a conference in Dammam was dropped, Ambassador Morris reported to the Foreign Office about a conversation he had had with King Faisal, in which the King confirmed that there was no point in continuing the negotiation process unless Shaikh Zayid accepted his proposal. ${ }^{57}$

King Faisal also warned that if Shaikh Zayid did not accept the Saudi offer, he would retract it and return to Saudi Arabia's 1949 claim to 80 percent of Abu Dhabi's territory, including the Al-Ain/Buraimi oasis region. ${ }^{58}$ Furthermore, he threatened to resolve the disputed areas with or without negotiations. In addition there are many reports that hint at the possible use of force by the Saudis if the disputed areas were not resolved on King Faisal's terms and prior to completion of the British withdrawal from the Gulf in late 1971.

Interestingly, not all the Saudi pressure on Shaikh Zayid came from King Faisal and the Saudi central government. Late in June 1970 the governor of Saudi Arabia's Eastern Province wrote to Shaikh Zayid, complaining that:

We have been informed by our patrols that patrols belonging to your government have entered Saudi territory on a number of occasions and have stationed themselves at water wells, which have been dug by ARAMCO. In particular there was a patrol in the early part of this months commanded by an English captain. ${ }^{59}$

The governor's letter represents the tactic of harassment, which involves actions designed to annoy the other negotiating party to gain compliance with demands. ${ }^{60}$ In response to that particular instance of harassment, Abu Dhabi denied the Saudi claim and apparently nothing further came of it; however, the incident illustrates Saudi efforts to keep direct pressure on Shaikh Zayid. By mentioning that a British officer was in command of an Abu Dhabi patrol, the Saudis also indirectly pressured the British.

An informant in Beirut also told the British that King Faisal had lost his temper with Shaikh Zayid for failing to accept his proposal. ${ }^{61}$ Importantly, anger can signal a negotiator's unwillingness to move from a positional commitment, ${ }^{62}$ and suggests that from May 1970 onwards this might have been King Faisal's aim.

I could not find any statements or even a hint in the documents cited in Arabian Boundaries that the Saudi tactic of 'take it or leave it' and/or the Saudi refusal to negotiate over King Faisal's proposal were in any way responsible for hindering progress on the negotiations. The Saudis insisted that Saudi sovereignty over the disputed areas claimed by King Faisal was non-negotiable. However, their contentious tactics produced mixed results. On the one hand, Shaikh Zayid met many of King Faisal's demands, ${ }^{63}$ but resisted making territorial concessions on the basis of the Saudi offer of 4 May 1970. On the other hand, the desire not to upset King Faisal gave the British another reason to push for a quick settlement, regardless of possible negative outcomes for Shaikh Zayid.

Given Saudi Arabia's strength in comparison with Abu Dhabi, and Britain's belief that the dispute should be settled quickly as King Faisal wished, it is not surprising that the Saudis never dropped their control negotiation strategy or the contentious tactics that supported it. Due to Saudi Arabia's power advantage, Shaikh Zayid did not have the necessary resources to punish Saudi Arabia effectively for its use of dirty tricks; nor did the British provide Abu Dhabi with those resources. Instead, they advised Shaikh Zayid to accommodate Faisal's demands.

\subsection{Playing the Al-Ain/Buraimi Card}

Historically both Abu Dhabi and Saudi Arabia had attached great importance to Al-Ain/Buraimi region, as John Duke Anthony discussed in 1975:

For Zayid, Buraimi has always been a very special oasis...in the center of the emirate's Eastern Province where, at Al-Ain, he spent most of his formative years prior to becoming Ruler. Until quite recently [Al-Ain/Buraimi] was also a major source, even though 90 miles away, of much of [Abu Dhabi's] water supply. For Faisal equally, the dispute over Buraimi was of special significance. To him, it was an issue of pride and honor, a reminder of past Wahhabi glories, and more recently, 
of a humiliating defeat inflicted by Zayid and the British when the Trucial Oman

Scouts drove Saudi forces from the area in $1955 .{ }^{64}$

On 15 May 1970, the British Foreign Office reviewed a report on the status of claims on Buraimi oasis made by Abu Dhabi and Saudi Arabia. The Foreign Office noted that Saudi Arabia had never dropped its claim to the Al-Ain/Buraimi oasis region. Furthermore, according to Foreign Office minutes, "[King Faisal] feels that his own personal honour and the prestige of Saudi Arabia are deeply involved and can only be satisfied by Abu Dhabi and the Sultanate's acceptance of the Saudi claim." ${ }^{65}$

Although the Foreign Office continued to receive reports of King Faisal's extreme anger over the failure to settle the dispute, by August, Dr Rashad Pharon, a senior Saudi official, had told Morris that: "if [Shaikh Zayid] would accept the Saudi proposals for the southern and western boundaries as they stand, then he thought that [King Faisal] would accept this as a settlement of the 'Buraimi problem' and drop his claims to the oasis without referendum or ascertainment." ${ }^{66}$ In a subsequent telegram to the Foreign Office, Morris recommended that: "we should immediately use all our powers of persuasion to get [Shaikh Zayid] to tell us he would acquiesce in the deal proposed by Dr. Pharon., ${ }^{\circ 7}$

In view of Saudi resentment at Britain's past history of humiliating Saudi Arabia and expelling Saudi forces from Buraimi in $1955^{68}$, the offer which they were now making to drop their claim to Buraimi was clearly seen by them as a major concession. The move was also interpreted by the British a significant concession. Thus, the British urged Shaikh Zayid to accept King Faisal's terms.

The view from Abu Dhabi and Oman, however, was different. The Ruler of Abu Dhabi and the Sultan of Oman had been jointly administering the Al-Ain/Buraimi oasis region since 1869, after they had expelled Saudi forces. ${ }^{69}$ Their sovereignty over the region was temporarily disrupted in 1952, when Saudi Arabia occupied Hamasa. It could in fact be argued that, by playing the Al-Ain/Buraimi card through publicly maintaining a claim on the oasis during the 1970s and onwards, and informing the British of the possibility of dropping the claim, the Saudis were perhaps responding to the political reality of Abu Dhabi's sovereignty over Al-Ain/Buraimi. As early as 3 June 1970, C. J. Treadwell, Political Agent in Abu Dhabi, reported that: "the Saudis should be discouraged from thinking that the oasis might be negotiable. Political and strategic considerations aside, [Shaikh Zayid] would encounter the strong opposition of his family if he admitted that the Saudis had a right to be heard on this issue."70 There were also "hawks" in Shaikh Zayid's government who strongly opposed both major territorial concessions by Abu Dhabi, and disagreed with Britain's advice to Shaikh Zayid about settling the dispute. ${ }^{71}$ In the UAE perspective, the Saudi offer to drop the Al-Ain/Buraimi claim was more a recognition of reality than a significant concession.

Playing the Al-Ain/Buraimi card could be interpreted as a negotiating tactic aimed at creating the impression that the Saudis were engaged in making mutual concessions in the negotiation process. Compromise and concession, according to Cohen, are dishonourable in Arab culture unless compromise and concession are mutual. ${ }^{72}$ Thus, using the Al-Ain/Buraimi card in the negotiation process may have given an impression that the disputing parties were actually involved in a mutual process to resolve their dispute peacefully. This study concludes that playing the Al-Ain/Buraimi card was a Saudi attempt to appear reasonable and legitimate.

\section{Abu Dhabi's Negotiation Strategy and Tactics}

During the negotiation process Shaikh Zayid, who wished to keep Abu Dhabi territory in the West and South, had no clear negotiating strategy, largely because he had depended on British mediation as a factor that would improve Abu Dhabi's position. Instead, the British pushed him to settle the dispute on King Faisal's terms with the result that he found himself almost exclusively on the defensive against Saudi "take it or leave it" tactic and British persuasion. Abu Dhabi was too weak to make effective use of any "tit-for-tat" "73 tactics to reward cooperative Saudi behaviour or punish competitive Saudi behaviour, and because he was discouraged by the British from making any counter-offers, Shaikh Zayid initially began to yield to Saudi demands.

Regarding the "tit-for-tat" strategy, Pruitt and Carnevale note that when one party to a dispute does not cooperate in negotiations, the other party is perceived as forceful. As a result, the first party may decide to choose collaboration over non-cooperation, with the possible risk that the second party might exploit the first party's collaboration, although it is felt that the second party is unlikely to try to take an advantage of the first party. ${ }^{74}$ Unfortunately, this explanation overlooks the central role of power in the "tit-for-tat" strategic model, since for such a strategy to succeed, the party that employs it must have enough power to punish or reward the other party's actions. 
In the context of the "tit-for-tat" model proposed by Pruitt and Carnevale, Shaikh Zayid could have expected cooperative behaviour from King Faisal. However, Saudi Arabia consistently exploited Abu Dhabi's collaborative behaviour and took advantage of Shaikh Zayid's positive response. For example, following King Faisal's May 1970 proposal, Shaikh Zayid gave the impression that he "would not reject the Saudi proposal out of hand."75 As noted previously, King Faisal requested Shaikh Zayid to stop drilling at Zararah, and on 18 May Shaikh Zayid sent a letter to King Faisal reporting that: "following my discussion with your Majesty on the 4th of May, I wish to inform your Majesty that there is now no drilling at [Zararah well] no. 1 and that I and my advisors are giving careful consideration to your Majesty's proposals." ${ }^{, 76}$ In this context, Shaikh Zayid's actions were consistent with a negotiator who was eager to establish a cooperative negotiation process.

However, on 25 May, Ambassador Morris in Jeddah informed the Foreign Office that Aramco had sent two aerial photography missions to verify Shaikh Zayid's claim that drilling had indeed stopped at Zararah well no.1. This mission had verified Shaikh Zayid's claim, but had also brought back aerial photographs of rigs going up at Zararah well no.3. Aramco officials then "directed King Faisal to issue the policy of [sus]pending drilling in the whole [Zararah] area not only on well no. one."77 Thus, the Saudis responded to Shaikh Zayid's cooperative gestures by escalating demands for a halt to ADPC's activities in the whole area.

As defined by Pruitt and Carnevale, trust, as an "expectation that the other party will cooperate in the future"78 was missing right from the beginning of the negotiation process. The Saudis did not trust Shaikh Zayid's word about stopping drilling at Zararah well no.1 and relied on Aramco to verify that the Shaikh had told King Faisal the truth. After the Saudis shifted their focus from one oil well to all ADPC activity in the Zararah area, Shaikh Zayid had less reason to trust the Saudis as well. By September $1970 \mathrm{Mr}$. Coles, Political Agent at Dubai, was reporting to the Foreign Office that Shaikh Zayid believed "if [King Faisal] was given an inch he would want an ell ${ }^{79}$ and it was therefore better to begin by offering very little." 80

Churchman states that negotiators who do not want a reputation for making negotiable offers will make small concessions, often at no cost to themselves. ${ }^{81}$ In this context, and according to Mana Saeed al-Otaiba, the former UAE Oil Minister, Shaikh Zayid's offer suggested that he did not trust the Saudis and had begun by making only small concessions, since he had not developed a dominant consensus within Abu Dhabi that favoured conceding substantial territory to the Saudis. ${ }^{82}$ By April 1971, Shaikh Zayid had offered to concede access rights to Khor alUdaid to the Saudis. ${ }^{83}$ Otaiba told the Political Agent in Abu Dhabi that Shaikh Zayid had been eager to make the Saudis an offer but had not yet convinced all the other Shaikhs in Abu Dhabi to agree to territorial concessions in either the west or the south. ${ }^{84}$ But on 28 October 1971, Sir William Luce wrote to I. S. Winchester in Jeddah to say that Shaikh Zayid had told him that: "the most he was prepared to offer the Saudis was an oil profit sharing zone, with joint sovereignty, and a strip of his southern border twenty kilometres wide at its widest point. ${ }^{\prime \prime 85}$ By this time, the British were aware that King Faisal had absolutely rejected any settlement involving shared revenues or joint sovereignty.

Regarding the issue of a neutral zone, a senior Saudi official explained that the Saudi experience of a neutral zone with Kuwait had created problems. When the Saudis rejected proposals that included joint sovereignty or the creation of a neutral zone, official analysis by the British supported the Saudi case. For example, creating a neutral zone was thought to be a problematic issue that concerned the rights of American and British oil companies with existing concessions, and the different perspectives of the British and the Saudis towards the definition of the south eastern frontier lines. ${ }^{86}$

The Saudis had previously experienced problems of this kind in the administration of the neutral zone with Kuwait, and in November 1970, the Foreign Office had told the Bahrain Political Residency that: "the Saudis were not prepared for such problems to be raised again in the Abu Dhabi/Saudi Arabia context." ${ }^{\circ 7}$ However, as a result of Saudi inflexibility the British now had to focus on Abu Dhabi's approach to negotiating the dispute.

\section{Conclusion}

One of the major factors that hindered the dispute's resolution was the British role. This study concludes that the British mediation role was definitely passive for Abu Dhabi. In the early 1970s, official British policy declared Britain's new role of "honest broker" or neutral mediator in dealing with the dispute. From the beginning, it was, in practice, an unlikely role for Britain to play since the British had substantial direct interests in the disputed areas, specifically in Zararah oilfield with respect to the activities of the ADPC. The involvement of British interests in the disputed areas restricted the role of the British to managing the dispute and carrying messages from Saudi Arabia to Abu Dhabi, which did not help to move the negotiation process forward. The records for 1970-71 included in Arabian Boundaries make it clear that the Saudis expected the British to pressure Abu Dhabi into accepting Saudi Arabia's terms, and that the British attempts to influence Shaikh Zayid to accept King Faisal's 
proposals failed. It was a significant failure, since a high priority for Britain had been either a temporary settlement, or, if possible, any solution at all to the matter of disputed areas, prior to British withdrawal from the Gulf in late 1971. The reason underlying Britain's reduced involvement in the dispute was due to its refusal to make any serious commitment to its obligations to Abu Dhabi under the Exclusive Agreement of 1892 that might damage its relations with either Abu Dhabi or Saudi Arabia.

The second factor that hindered the dispute's resolution was the Saudi control negotiation strategy. It concludes that Saudi Arabia entered negotiations with the fixed strategic goal, presented in King Faisal's proposal of 1970, of obtaining recognition of claims to territory in the southern and western areas of Abu Dhabi. To implement that goal, the Saudi government used control strategy, employed inflexible positions and a range of negotiation tactics that fall into the "contentious tactics" and "dirty tricks" categories. The only concession beyond King Faisal's May 1970 proposal was the dropping of the claim to the Al-Ain/Buraimi region. In contrast, Shaikh Zayid's position and Abu Dhabi's negotiating strategy and tactics seem to have become somewhat confused due to the limited role of the British. By 1970-71, the British were attempting to persuade Shaikh Zayid to settle the dispute on King Faisal's terms, with the result that Shaikh Zayid found himself on the defensive against Saudi Arabia's control strategy and British persuasiveness.

As British withdrawal from the Gulf approached, no settlement has been found to the disputed areas. Ambassador Morris in Jeddah had told the Foreign Office that: "our difficulty has always been to persuade [Shaikh Zayid] to meet [King Faisal's] demands in the south and west." ${ }^{" 88}$ The Ambassador's remark reflected a consensus that had developed among British officials by 1971 that Shaikh Zayid was the major obstacle to the settlement of the disputed areas. When the British withdrew officially the disputed areas remained unsettled because the gap between Abu Dhabi and Saudi Arabia remained as wide as ever.

\section{Copyrights}

Copyright for this article is retained by the author(s), with first publication rights granted to the journal.

This is an open-access article distributed under the terms and conditions of the Creative Commons Attribution license (http://creativecommons.org/licenses/by/3.0/).

1 Author's Note: The term Abu Dhabi has been applied somewhat interchangeably in the text. Historically (1820-1971) the border dispute was between the Emirate of Abu Dhabi and Saudi Arabia. However, following Britain's military withdrawal from the Gulf on 1 December 1971, and because the United Arab Emirates become an independent state on 2 December 1971, I have used UAE when referring to the border dispute with Saudi Arabia after that date.

${ }^{2}$ Foreign Office Minutes by J. M. Edes, 'Abu Dhabi/Saudi Arabia Frontier Dispute,' 23 September 1970, FCO8/1340, TNA, London, in Arabian Boundaries, vol. 11, ed. Schofield, p. 698.In practice the role of honest broker was an unlikely one for Britain to play, because the British had direct and substantial interests in the disputed areas, namely the Zararah oilfield in Liwa oasis. Their passive role reflects an intention to avoid their obligations to Abu Dhabi under the Exclusive Agreement of 1892, which would remain in effect until 30 November 1971.

3 Al-Ain/Al-Buraimi oasis region consists of nine oases/villages, seven of which - Al-Ain, Al-Jaheli, Al-Qattarah, Al-Muwaiji, Al-Hill, Al-Masudi, and Al-Muhtaredh - are today under Abu Dhabi's control, while the remaining three, namely Hamasa, Sa'ara and Buraimi, today belong to the Sultanate of Oman.

${ }^{4}$ The term in Arabic means an inlet from a large body of water. Khor al-Udaid is a shallow inlet located on the eastern side of the base of the Qatar peninsula. A coastal inlet at the intersection between modern-day Abu Dhabi, Qatar, and Saudi Arabia

${ }^{5}$ King Faisal had initially offered a referendum over Buraimi, but offered to drop his claim to Buraimi in June 1970.

${ }^{6}$ Foreign Office Minutes by J. M. Edes, 'Oil Company Drilling in Abu Dhabi,' 11 November 1970, FCO8/1314, TNA, London, in Arabian Boundaries, vol.11, ed. Schofield, p.771. 
7 A. Reeve \& S. L. Egerton (Abu Dhabi) to (Foreign Office), "Abu Dhabi/Saudi Arabia: ADPC Drilling at Zarrara", 8 March 1971, FCO8/1613, TNA, London, in Arabian Boundaries, , vol.12, ed. Schofield, pp. 259-260

${ }^{8}$ Sir S. Crawford (Bahrain), to (FCO), 10 June 1970, FCO8/1335, TNA, London, in Arabian Boundaries, vol. 11, ed. Schofield, p. 252.

${ }^{9}$ Thomas Princen, Intermediaries in International Conflict (Princeton University Press, 1992), p. 23.

${ }^{10}$ See Figure. 1, p 143

${ }^{11}$ Letter No DD/Sep D. Nixon, Withers, (London), to J. M. Edes, (Foreign Office), 29 December 1970, FCO8/1341, TNA, London in Arabian Boundaries, ed. Schofield, vol. 11, p. 844.

12 W. Morris (Jedda) to (FCO), 12 June 1970, FCO8/1335, TNA, London, in Arabian Boundaries, vol.11, ed. Schofield, p.256.

${ }^{13}$ L. N. Rangarajan, The Limitation of Conflict: a Theory of Bargaining and Negotiation (London: Croom Helm, 1985), p 84

14 The Exclusive Agreement of 1892 would expire on 30 of November 1971, though it was still in effect when Shaikh Zayid attempted to act independently of the British.

${ }^{15}$ UAE diplomat, Interview, Washington, 25 November 2010.

${ }^{16}$ Sir S. Crawford (Bahrain), to (Foreign Office), 29 May 1970, FCO8/1334, TNA, London in Arabian Boundaries, vol. 11, ed. Schofield, p.127.

17 A. C. Goodison (Kuwait), to (FCO), "Shaikh Zayid's visit to Riyadh", 6 May 1970, FCO8/1332, TNA, London, in Arabian Boundaries, vol. 11, ed. Schofield, p. 846.

${ }^{18}$ W. Morris, British Ambassdor in Jeddah (Deleted in yellow) (Jeddah), to (FCO) 6 May 1970, FCO8/1332, TNA, London, in Arabian Boundaries, vol. 11, ed. Schofield, 1970, p. 848.

19 W. Morris (Jedda), to (Foreign Office), 6 May 1970, FCO8/1332, TNA, London, in Arabian Boundaries, vol. 11, ed. Schofield, p. 848.

${ }^{20}$ Foreign Office minute by A. A. Acland, Abu Dhabi-Saudi Arabia, 15 June 1970, FCO8/1337, TNA, London, in Arabian Boundaries, vol. 11, ed. Schofield, p.365.

${ }^{21}$ Mr. Jim Treadwell (Beirut) to (Foreign Office), 31 May 1970, FCO8/1334, TNA, London, in Arabian Boundaries, vol. 11, ed. Schofield, p.141

${ }^{22}$ Mr. Goodison (Kuwait), to (FCO), 19 May 1970, FCO8/1334, TNA, London, in Arabian Boundaries, vol. 11, ed. Schofield, p.945.

${ }^{23}$ W. Morris (Jedda), to the (FCO), 6 May, 1970, FCO8/1332, TNA, London in Arabian Boundaries, vol. 11, ed. Schofield, p. 849.

${ }^{24}$ N.J. Barrington (Foreign Office), to P.J.S Moon, 28 May 1970, FCO8/1334, TNA, London, in Arabian Boundaries, vol. 11, ed. Schofield, p. 118.

${ }^{25}$ Mr. Jim Treadwell (Beirut) to (Foreign Office), 31 May 1970, FCO8/1334, TNA, London, in Arabian Boundaries, vol. 11, ed. Schofield, p.141.

${ }^{26}$ A. J. D. Stirling (Bahrain) Agency to, Sir S Crawford Bahrain Residency, 'Abu Dhabi/Saudi Arabia,' 16 May 1970, FCO8/1334, TNA, London in Arabian Boundaries, vol.11, ed. Schofield, p. 71. 
${ }^{27}$ There were other regional mediators involved in the UAE-Saudi border dispute - for example, Jordan, Pakistan, Egypt, etc. from 1970 to 1974. The activities of these regional mediators were interrupted by British attempts to control mediator involvement. After the Britain withdrew its military from the Gulf in December 1971 and granted independence to the emirates, the UAE relied almost exclusively on Qatari mediation.

28 A. J. D. Stirling (Bahrain) Agency to Sir S Crawford, Bahrain Residency, 'Abu Dhabi/Saudi Arabia', 16 May 1970, FCO8/1334, TNA, London, in Arabian Boundaries, vol. 11, ed. Schofield, p. 71.

${ }^{29}$ (Foreign Office), to (Bahrain) Mr. Steward, Bahrain Residency, 19 June 1970, FCO8/1337, TNA, London in Arabian Boundaries, vol. 11, ed. Schofield, p. 380.

${ }^{30}$ Mr. Stewart (Bahrain), to (Foreign Office), 16 May 1970, FCO8/1332, TNA, London in Arabian Boundaries, vol. 11, ed. Schofield, p.892.

31 (Foreign Office) to (Bahrain), 27 May 1970, FCO8/1334, TNA, London, in Arabian Boundaries, vol. 11, ed. Schofield, pp. 90-91.

32 Foreign Office minutes by A. A. Acland, “Abu Dhabi/Saudi Arabia”, 15 May, 1970, FCO8/1333, TNA, London in Arabian Boundaries, vol. 11, ed. Schofield, p. 936.

${ }^{33}$ (Foreign Office) to (Bahrain), 29 May 1970, FCO8/1334, TNA, London, in Arabian Boundaries, vol. 11, ed. Schofield, p.132.

${ }^{34}$ Foreign office minutes by A. A. Acland, "Abu Dhabi-Saudi Arabia frontier Dispute, 1 June 1970, FCO8/1335, TNA, London, in Arabian Boundaries, vol. 11, ed. Schofield, p.158.

${ }^{35}$ Note from N. J. Barrington, to P. J. S. Moon, Foreign Office, 28 May 1970, FCO8/ 1334, TNA, London, in Arabian Boundaries, vol. 11, ed. Schofield, p.811.

${ }^{36}$ Letter, C. M. Dalley (Abu Dhabi Petroleum Company Ltd), to the (Foreign Office), enclosure: paper on scope and extend of ADPC's operations in the territory of Abu Dhabi, 2 June 1970, FCO8/1335, TNA, London, in Arabian Boundaries, vol. 11, ed. Schofield, p.197.

${ }^{37}$ Letter, T Brant (Foreign Office), to I.G. MacPherson, (Abu Dhabi Petroleum Company), 'Saudi Arabia/ Abu Dhabi,' 24 July 1970, FCO8/1339, TNA, London in Arabian Boundaries, vol. 11, ed. Schofield, p. 568.

${ }^{38}$ Morris (Jedda) to (Foreign Office), 28 May 1970, FCO8/1334, TNA, London in Arabian Boundaries, vol. 11, ed. Schofield, p. 97.

39 The British offered a modified Riyadh line that came close to the Abu Dhabi coast and included the Sufuk wells (which bordered the Saudi line 25 miles to the west of Abu Dhabi) as Saudi territory.

${ }^{40}$ Foreign Office Minutes by J.M. Edes, “Oil Company Drilling in Abu Dhabi”, 11 November 1970, FCO8/1341, TNA, London, in Arabian Boundaries, vol. 11,ed. Schofield, pp.769-772.

${ }^{41}$ A. A. Acland (Foreign Office), to C. J. Treadwell (Abu Dhabi), 'ADPC and Zarara,' 25 March 1971, FCO8/1614, TNA, London, in Arabian Boundaries, vol. 12, ed. Schofield, p.289.

${ }^{42}$ C. J. Treadwell (Abu Dhabi), to A.A. Acland (Foreign office), 'ADPC and Zarara,' 4 April 1971, FCO8/1614, TNA, London, in Arabian Boundaries, vol. 12, ed. Schofield, p. 300.

${ }^{43}$ Foreign Office Minutes by A. Reeve, 'ADPC and Zarara', 23 April 1971, FCO8/1614, TNA, London, with Additional Minutes by S. L. Eggerton, 25 April 1971”, in Arabian Boundaries, vol.12, ed. Schofield, p.326.

${ }^{44}$ Foreign Office Minutes by J.P. Bannerman, 'Rights of Oil Concessionaries and the Abu Dhabi/Saudi Frontier Dispute', 4 October 1972, FCO8/1813, TNA, London, in Arabian Boundaries, vol. 13, ed. Schofield, pp. 
$520-521$.

${ }^{45}$ The federation of nine was intended to consist of Qatar, Bahrain and the seven Emirates (Abu Dhabi, Ajman, Dubai, Fujairah, Ras al-Khaimah, Sharjah, and Umm al-Quwain and Ras al-Khaimah).

${ }^{46}$ C.J. Treadwell (Abu Dhabi), to G. G. Arthur, Bahrain Residency (Bahrain), 'Abu Dhabi/ Saudi Arabia,' 5 April 1971, FCO8/1614, in Arabian Boundaries, vol. 12, ed. Schofield, p. 312.

47 A. A. Acland (Foreign Office) to W Morris (Jedda), 'Abu Dhabi/ Saudi Arabia,' 8 July 1971, FCO8/1615, in Arabian Boundaries, vol. 12, ed. Schofield, pp. 391-392.

${ }^{48}$ Hussam Al-Ulama, Interview, Washington DC, 10 November 2010.

${ }^{49}$ Roger Fisher and William Ury, Getting to Yes: Negotiating Agreement Without Giving In, with editorial input by Bruce Patton, 1st ed. (Boston: Houghlin Mifflin, 1981), p. 140.

${ }^{50}$ Foreign Office Minutes by A. A. Acland, ‘Abu Dhabi/ Saudi Arabia, enclosing copy of despatch No 3/5 from W. Morris, Jeddah, to A. A. Acland, Foreign Office, "The Abu Dhabi Boundary Kamal Adham and the Way Ahead”, FCO8/1337, 15 June 1970, London, TNA, in Arabian Boundaries, vol.11, ed. Schofield, p.367.

${ }^{51}$ United Sates Government Memorandum, from Brooks Wrampelmeier to Mr. Davies, "Situation in the Persian Gulf”, 10 August, 1970, File No.A1-5666, National Archives, College Park, Maryland.

${ }^{52}$ United State Government Memorandum, from Richard, "Meeting with Parsons Regarding Persian Gulf," 27 September, 1971, File No.A1-5666, National Archives, College Park, Maryland.

${ }^{53}$ Mohamed Rabie, Conflict Resolution and Ethnicity (London: Praeger, 1994), p.71.

${ }^{54}$ Raymond Saner, The Expert Negotiator, 2nd ed. (Leiden: MartinusNijhoff Publishers, 2005), pp. 107-111. Also see Phil Baguley, Effective Communication for Modern Business (London: McGraw-Hill, 1994), p. 68.

55 Fisher and Ury, Getting to Yes, p.148.

56 (Abu Dhabi), to (Bahrain), 23 November 1970, FCO/1615, TNA, London, in Arabian Boundaries, vol. 11, ed. Schofield, p. 477.

57 W. Morris (Jedda), to (Foreign Office), 23 August 1970, FCO8/1339, TNA, London, in Arabian Boundaries, vol. 11, ed. Schofield, p. 626.

${ }^{58}$ W. Morris (Jedda), to (Foreign Office), 23 August 1970, FCO8/1339, TNA, London, in Arabian Boundaries, vol. 11, ed. Schofield, p.626.

${ }^{59}$ Letter C. E. Morgan (Abu Dhabi) to T. Brant (Foreign Office), 9 July 1970, FCO8/1338, TNA, London, in Arabian Boundaries, vol. 11, ed. Schofield, p. 496.

${ }^{60}$ Pruitt and Carnevale, Negotiation in Social Conflict, p.32.

${ }^{61}$ Mr. Jim Treadwell (Beirut) to (Foreign Office), 31 May 1970, FCO8/ 1334, TNA, London, in Arabian Boundaries, vol. 11, ed. Schofield, p.141.

${ }^{62}$ Churchman, Negotiation: Process, Tactics, p. 10.

${ }^{63}$ For more details on this, see Abu Dhabi-Negotiation Strategy and Tactics, p.9-10.

${ }^{64}$ John Duke Anthony, Arab Sates of the Lower Gulf: People, Politics, Petroleum (Washington: The Middle East Institute, 1975), p.148. 
${ }^{65}$ Foreign Office Minutes by A. A. Acland, 'Abu Dhabi/Saudi Arabia,' 15 May 1970, FCO8/1333, TNA, London, in Arabian Boundaries, vol. 11, ed. Schofield, p. 934.

${ }^{66}$ W. Morris, (Jedda), to (Foreign Office), 6 August 1970, FCO/1338, TNA, London, in Arabian Boundaries, vol. 11, ed. Schofield, p. 553.

${ }^{67}$ W. Morris (Jedda), to (Foreign Office), 8 August 1970, FCO8/1338, TNA, London, in Arabian Boundaries, vol.11, ed. Schofield, p.554.

${ }^{68}$ James F. Mandaville, “Confidential Memorandum to the File: Oman-South Yemen Border." William E. Milligan Papers. Box 2, Folder 5, Georgetown University Library, Special Collections Research Center, Washington DC. It is important to note that, under the British unilateral declaration of the Saudi frontier line of 1955, Abu Dhabi was left with Khor al-Udaid, the Liwa oasis, and the Al-Ain/Buraimi region.

69 "The Occupation of Buraimi by Sayyid Azzan b. Qais 1869-1870", in Records of The Emirates, Primary Documents 1853-1871, Vol. 3, ed. Penelope Tuson (Oxford: Archive Editions, 1990), pp. 386-407.

${ }^{70}$ Mr. Treadwell (Abu Dhabi), to (FCO), 'Abu Dhabi/ Saudi Arabia,' 3 June 1970, FCO8/1335, TNA, London, in Arabian Boundaries, vol.11, ed. Schofield, p.216.

71 "Hawks" in Shaikh Zayid's government were firmly opposed to the idea that Buraimi belonged to Saudi Arabia and pushed Shaikh Zayid not to accept the Saudi argument.

72 Raymond Cohen, "Cultural Aspects of International Mediation", in Jacob Bercovitch, ed. Resolving International Conflicts (London: Lynne Rienner Publishers, 1996), p113.

73 Pruitt and Carnevale, Negotiation in Social Conflict, p. 78.

${ }^{74}$ Ibid., p.73.

${ }^{75}$ Mr. Treadwell (Abu Dhabi), to (Foreign Office), 16 May, 1970, FCO8/1332, TNA, London, in Arabian Boundarie, vol. 10, ed. Schofield, p.904.

${ }^{76}$ Wright (Foreign Office), to HH Shaikh Zaid bin Sultan Al Nahiyan, Ruler of Abu Dhabi, 18 May 1970, FCO8/1333, TNA, London, in Arabian Boundaries, vol. 11, ed. Schofield, p. 13.

77 Mr. W. Morris (Jedda), to (Foreign Office), 25 May 1970, FCO8/1333, TNA, London, in Arabian Boundaries, vol. 11, ed. Schofield, p.66.

${ }^{78}$ Pruitt and Carnevale, Negotiation in Social Conflict, p.133.

79 An obsolete English unit of length, mainly for measuring cloth, of approximately 1.14.metres/45 inches

${ }^{80}$ Mr. Coles (Dubai), to (Foreign Office), 8 September 1970, FCO8/1339, TNA, London, in Arabian Boundaries, vol.11, ed. Schofield, p. 653.

${ }^{81}$ Churchman, Negotiation: Process, Tactics, Theory, p.18.

82 C. J. Treadwell (Abu Dhabi), to Bahrain Residency (Bahrain) 27 April 1971, FCO8/1614, TNA, London, in Arabian Boundaries, vol. 12, ed. Schofield, pp.337-338.

${ }^{83}$ R. D Hart, Bahrain Residency, (Bahrain) to Reeve, (Foreign Office), 'Abu Dhabi Surveys,' 27 April 1971, FCO8/1614, TNA, London, in Arabian Boundaries, vol. 12, ed. Schofield, pp.340-341.

${ }^{84}$ C. J. Treadwell (Abu Dhabi), to Bahrain Residency (Bahrain) 27 April 1971, FCO8/1614, TNA, London, in Arabian Boundaries, vol. 12, ed. Schofield, pp.337-338. 
${ }^{85}$ W.H. Luce (Bahrain Residency), to L.S. Winchester (Jedda), 'Abu Dhabi/Saudi Arabia', 5 November 1971, Enclosing "Extract From Record of Conversation with the Ruler of Abu Dhabi on Thursday, 28 October 1971", FCO8/1615, TNA, London, in Arabian Boundaries, vol. 12, ed. Schofield, p.467.

${ }^{86}$ Foreign Office minutes by J.P Bannerman, 28 October 1970, J. M. Edes, 28 October1970, A. A. Acland, 29 October 1970, A. Reeve, 2 November 1970, enclosing paper, "Factors Affecting the Establishment of a Saudi-Abu Dubai Neutral Zone", 27 October 1970, FCO8/1340, TNA, London, in Arabian Boundaries, vol. 11, ed. Schofield, pp. 743-751.

${ }^{87}$ (Foreign Office) to G. G Arthur, Bahrain Residency (Bahrain) ‘Abu Dhabi/ Saudi Arabia,' 5 November 1970, FCO8/1340, TNA, London, in Arabian Boundaries, vol.11, ed. Schofield, p.759.

${ }^{88}$ Foreign Office Minutes by A Reeve, 'Abu Dhabi /Saudi Arabia,' 23 April 1971, FCO8/1614, TNA, London, in Arabian Boundaries, vol. 12, ed. Schofield, p.324. 